\title{
TRENDS IN POPULATION SIZE OF OPHRYS ARGOLICA SUBSP. BISCUTELLA IN THE APPENNINO LUCANO-VAL D'AGRI-LAGONEGRESE NATIONAL PARK (ITALY)
}

\author{
Vito A. Romano, Leonardo Rosati", Simonetta Fascetti \\ University of Basilicata, Italy \\ *e-mail: leonardo.rosati@unibas.it
}

Received: 06.04.2020. Revised: 07.09.2020. Accepted: 11.09.2020.

\begin{abstract}
In this study we focused on population monitoring of Ophrys argolica subsp. biscutella, an orchid endemic to the south of the Italian Peninsula belonging to the section Araniferae. The study concerned its main detected population located within the Appennino Lucano-Val d'Agri-Lagonegrese National Park (Basilicata Region, South Italy). Ten permanent plots of $10 \times 10 \mathrm{~m}$ were annually surveyed from 2010 to 2015 using total counts of flowering plants. The following characters were measured: height of inflorescences, number of flowers, lost plants, fruiting plants and fruit set. Percentage cover of trees, shrubs, herbs and bare rocks were visually estimated in $1 \times 1 \mathrm{~m}$ subplots and an accurate vegetation map of each plot was drawn. In regards to plant height and reproductive variables, no significant differences between the plots were detected. Similarly, with respect to population variables, no significant correlations with vegetation and environmental features (i.e. slope, aspect) emerged. On the contrary, a strong negative trend in the population size was observed (from 237 individuals in 2010 to 61 in 2015) and the number of plants per plot decreased from 23.7 individuals to 6.1 individuals. Reproductive variables (i.e. number of flowers, fruit set) showed a similar decreasing pattern. As for the lost of individuals we detected a higher incidence in 2011 (average number of lost plants per plot was 16.6) with $75 \%$ of lost spikes and fruit set amounting to zero. Although grazing management can heavily influence demographic parameters of Ophrys populations, there was no evidence of any kind of land cover or land use change. No appreciable differences were observed in vegetation cover, grazing type or grazing load. Moreover, no significant disturbance events occurred in this area. Finally, the inspection of meteorological data recorded during the monitoring interval lead to argue that the strong demographic decline of the Ophrys argolica subsp. biscutella population in the Appennino Lucano-Val d'Agri-Lagonegrese National Park must be mainly related to the late frost event that occurred in the spring of 2011.
\end{abstract}

Key words: demography, endemic species, late frost, Orchidaceae, population dynamics, Protected Area, rare plant species

\section{Introduction}

Climate change and land use modifications, including land abandonment, represent major threats to biodiversity (Sala et al., 2000). This is particularly true in Mediterranean regions, one of the recognised global hotspots of vascular plant diversity (Médail \& Myers, 2004). It is therefore important that frequent monitoring campaigns of rare and threatened plant populations are undertaken, to enable early warning of decline in native species populations or to document a new arrival of invasive plants (Rosati et al., 2020).

The genus Ophrys (Orchidaceae) has a Eurasian distribution, ranging from the Canary Islands to the Caspian Sea and from North Africa to South Scandinavia, even though most of the species are found around the Mediterranean basin, where they are almost exclusively growing on dry base-rich soils (Delforge, 2016). Flowering usually occurs in spring, when wintergreen leaf rosettes wither (Pridgeon, 1992). These orchids are well known for their sexually deceptive pollination mechanism, which involves mimicry of mating signals of their pollinators (Johnson \& Schiestl, 2016). The unusual pollination syndrome characteris- ing Ophrys species and the complex evolution of this genus are probably the reasons for the current confusing taxonomy. The estimate of the number of taxa varies between nine macro-species based on molecular analysis (Bateman et al., 2018) and 353 micro-species relying on minute morphological characters (Delforge, 2016). Indeed, recent floras and checklists for the Italian territory reported a number of taxa ranging from 24 species and subspecies (Pignatti, 1982) to 103, of which $23 \%$ being considered endemic (Bartolucci et al., 2018). This charismatic group of orchids aroused a huge interest in researchers for taxonomy, evolution and pollination biology (e.g. Devey et al., 2008; Cortis et al., 2009; Gervasi et al., 2017). Nevertheless, even though the knowledge of status and demographic trends is particular important to conduct effective management actions, especially in Protected Areas, only a few studies have focused on populations monitoring in the context of habitat management and conservation (e.g. Waite \& Hutchings, 1991). In this framework, it is worthy to note as the entire Orchidaceae family is listed in the Convention on International Trade in Endangered Species of Wild Fauna and Flora 
(CITES) and several species are included in the European Habitat Directive 92/43/EC (European Union, 1992), thus requiring specific monitoring action. As for Italy, the whole Orchidaceae family is legally protected in several of its administrative regions (i.e. Campania, Basilicata and Calabria) by specific Regional Laws.

Ophrys argolica subsp. biscutella (O.Danesch \& E.Danesch) Kreutz is a rare endemic taxon known from the south of the Italian Peninsula (Fig. 1). The discovery of a large population of this orchid in the Appennino Lucano-Val d'AgriLagonegrese National Park (South Italy) in 2005 prompted to document its demographic behaviour. In particular we mainly aimed to (i) assess the temporal trend of population size and reproductive parameters (i.e. fruit set); (ii) detect if available environmental variables are related to population size and trend.

\section{Material and Methods \\ Study species}

The southern Italian endemic Ophrys argolica subsp. biscutella belongs to subgenus Fuciflorae, section Araniferae. It is pollinated by Anthophora retusa (Linnaeus, 1758) and can be found in dry grasslands, garrigues, shrublands and opens woods, on stony carbonatic soils, from $280 \mathrm{~m}$ a.s.1. to 1100 m a.s.1. (Romolini \& Souche, 2012). Currently its presence is documented only for limited territories within the Italian administrative regions of Campania, Basilicata, Puglia and Calabria (Romolini \& Souche, 2012; Bartolucci et al., 2018) (Fig. 1). Ophrys argolica subsp. biscutella is considered only abundant in the territory of Gargano (Puglia), representing its locus classicus. In the recent monograph of Romolini \& Souche (2012) about the genus Ophrys in Italy, this taxon was considered at species rank, as Ophrys biscutella O.Danesch \& E.Danesch.
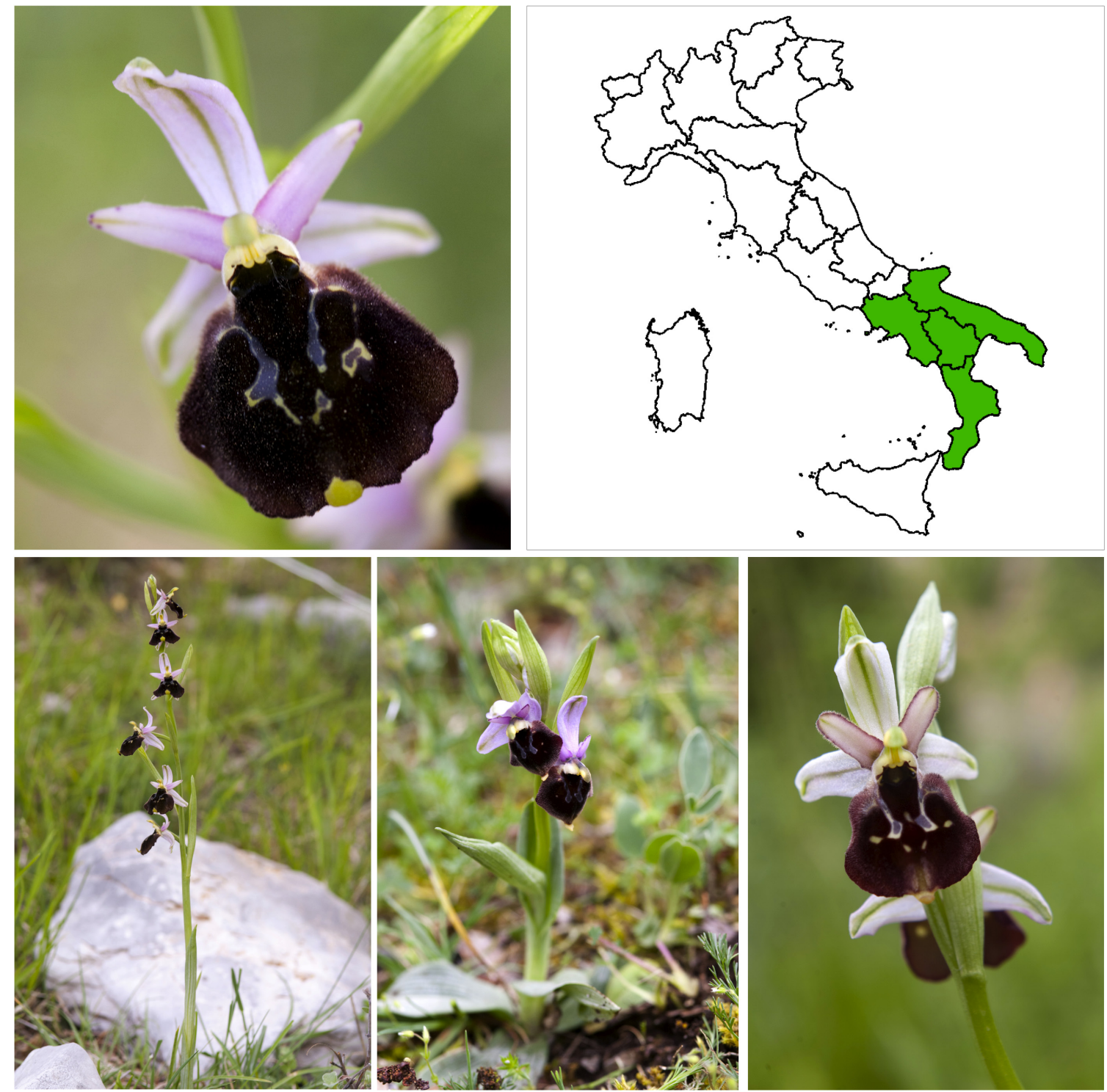

Fig. 1. The southern Italian endemic Ophrys argolica subsp. biscutella (O.Danesch \& E.Danesch) Kreutz, photographed in the Appennino Lucano-Val d'Agri-Lagonegrese National Park (photos made by V.A. Romano), and its occurrence within the Italian administrative regions (Source: http://dryades.units.it/floritaly/index.php?procedure=taxon_page\&tipo=all\&id=8147). 


\section{Study area}

The study area $\left(40.24841^{\circ} \mathrm{N}, 15.80157^{\circ} \mathrm{E}\right.$; altitude: $1050 \mathrm{~m}$ a.s.1.) is located on the southern Italian Peninsula (Moliterno municipality), and it is included in the Appennino Lucano-Val d'Agri-Lagonegrese National Park (NP). This NP, established in 2007, with a total area of $689.96 \mathrm{~km}^{2}$ (Fig. 2), represents one of the most recently established NPs in Italy. The study area is also entirely within the Natura 2000 site SCI IT9210110 «Faggeta di Moliterno». The site hosts a rich biodiversity of vascular plants, especially of orchids, with over 50 taxa recorded (Fascetti et al., 2006, 2013). This biotope is part of the Maddalena Mountains ridge, a sector of the Southern Apennines, made up of dolomite and limestone, forming a mountain ridge aligned in the NNW-SSE direction along the border between the administrative regions of Basilicata and Campania. The altitude reaches $1503 \mathrm{~m}$ a.s.l. at the top of the Mount Serra Longa. The precipitation regime is Mediterranean, with a peak in autumn and a marked decrease in summer. Annual rainfall registered at the thermopluviometric station of Moliterno (879 m a.s.l) amounts to $1094 \mathrm{~mm}$. The annual average temperature is $12.5^{\circ} \mathrm{C}$. The hottest month is August $\left(22.3^{\circ} \mathrm{C}\right)$ and the coldest one is January $\left(3.9^{\circ} \mathrm{C}\right)$ (Fascetti et al., 2013).

Botanists used to pay little attention to this sector in the southern Apennines. Only recently it has been thoroughly investigated (Fascetti et al., 2013; Rosati et al., 2017, 2019a,b).

The forest vegetation is dominated by Fagus sylvatica L., Quercus cerris L., Quercus pubescens Wild. or Ostrya carpinifolia Scop., depending on altitude, slope aspect and soil depth (Fascetti et al., 2013). Pastures are quite abundant and mainly comprise dry grasslands which replaced potential forest vegetation as a consequence of a century of burning and clear cutting practices to enhance livestock grazing. These pastures are developed on shallow base rich soils, frequently interrupted by outcrops of carbonatic substratum. They are dominated both by hemicryptophytes as Bromus erectus Huds, Koeleria splendens C.Presl, Stipa austroitalica Martinovský, Festuca circummediterranea Patzke and by chamaephytes as Lomelosia crenata (Cirillo) Greuter \& Burdet, Thymus striatus Vahl, Helianthemum canum (L.) Hornem. and Teucrium montanum L.

\section{Data and Methods}

Within the larger detected population of Ophrys argolica subsp. biscutella in the study area, we placed two transects, orthogonal to the mountain slope, each one including five contiguous $10 \times 10 \mathrm{~m}$ permanent plots. During 2010-2015, the plots were surveyed twice a year. The first visit was during the flowering period, while the second during the fruiting season. Every year, in order to determine the optimal starting date for the sampling, population phenology was monitored on a biweekly basis during the growing season (from late winter to the spring). Each plot was divided into 100 subplots of $1 \times 1 \mathrm{~m}$ to get the accurate position of each plant. The population size was estimated by way of total counts (Bullock, 1996), only considering flowering plants (i.e. juveniles and plantlets were not recorded since hardly distinguishable). Each individual was labelled and the following variables were retrieved for each subplot: number of flowering plants, height of inflorescences, number of flowers, number of plants lost (i.e. floral spikes recorded during the first days of the anthesis and subsequently rotted before the fruits ripening), number of fruiting plants and fruit set. Altitude, slope inclination, and aspect were also recorded at subplot level. The percentage cover of trees, shrubs, herbs and bare rocks were visually estimated at subplot level. At the start of the first year of sampling, an accurate vegetation map of each surveyed plot was drawn in the field (Fig. 3).

For the aim of this paper, data was aggregated at plot level $(n=10)$ and subjected to a statistical analysis using the PAST software (Hammer et al., 2001). The relationship between measured variables was tested by means of Spearman Rs correlation coefficient. Significance of pairwise comparisons between years of sampling was assessed using Mann-Whitney test and Bonferroni correction.

The daily temperature (mean, maximum and minimum) and precipitation, recorded for each year during the monitoring period by the nearest available meteorological station (Sarconi, altitude: $635 \mathrm{~m}$ a.s.1.; $40.247341^{\circ} \mathrm{N}, 15.890500^{\circ} \mathrm{E}$ ), were used to reveal relationship among population's trend and possible weather anomalies (i.e. number of frost days). We used these variables as they are the most detailed meteorological data available for the study area. Temperatures were corrected applying an altitudinal gradient of $0.65^{\circ} \mathrm{C}$ per $100 \mathrm{~m}$.

\section{Results}

The main population of Ophrys argolica subsp. biscutella in the Appennino Lucano National Park was recorded for six consecutive years, from 2010 to 2015. The flowering phase and, consequently, the optimal period of data collections, occurred in this interval between the last week of April and the first week of May, with a slight shift forward or backward according to between-years differences in spring temperatures. 

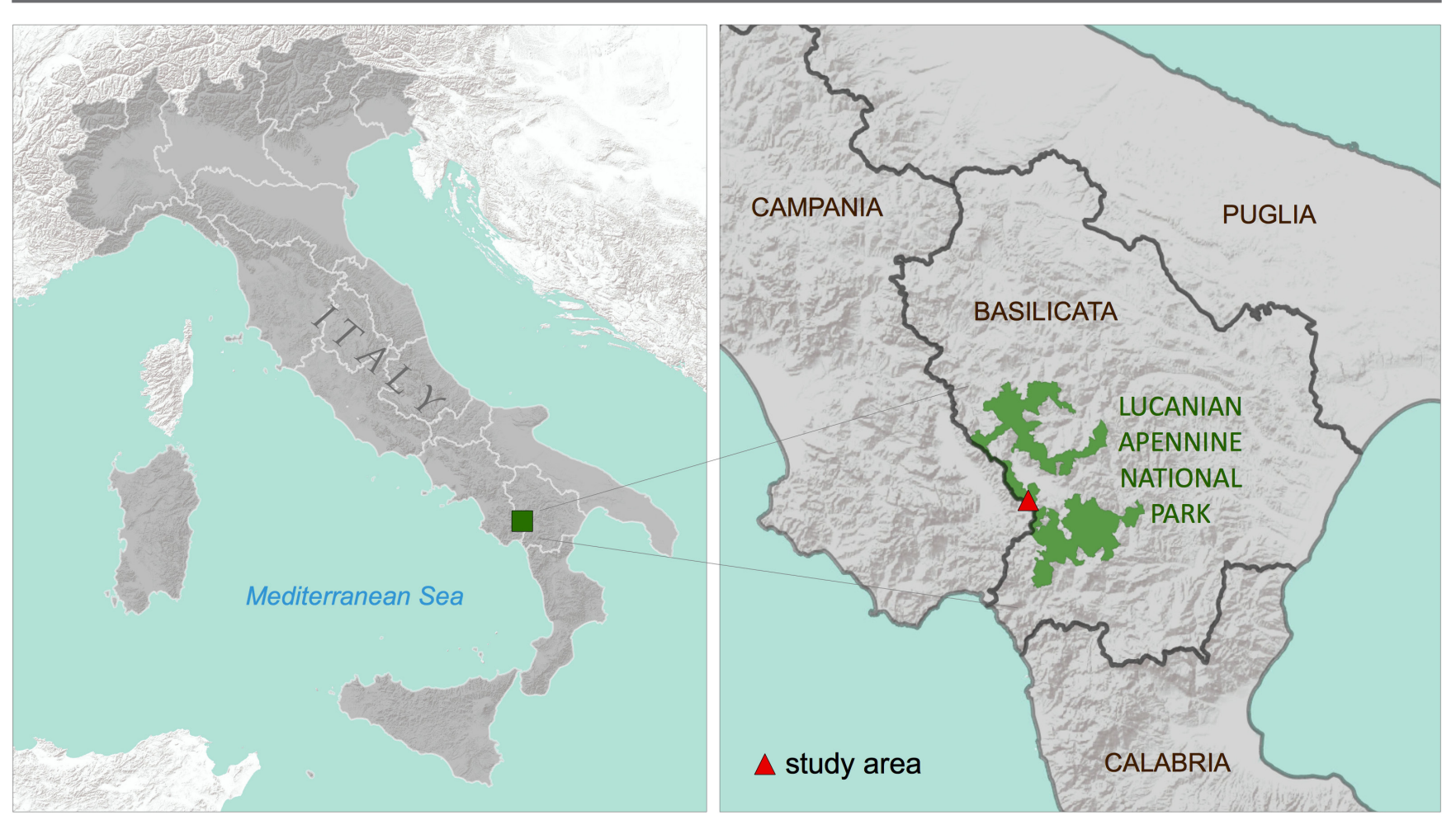

Fig. 2. Location of the study area where the population of Ophrys argolica subsp. biscutella was monitored during 20102015. In grey is drawn the border of Italian administrative regions, in green the limit of the Appennino Lucano-Val d'AgriLagonegrese National Park.

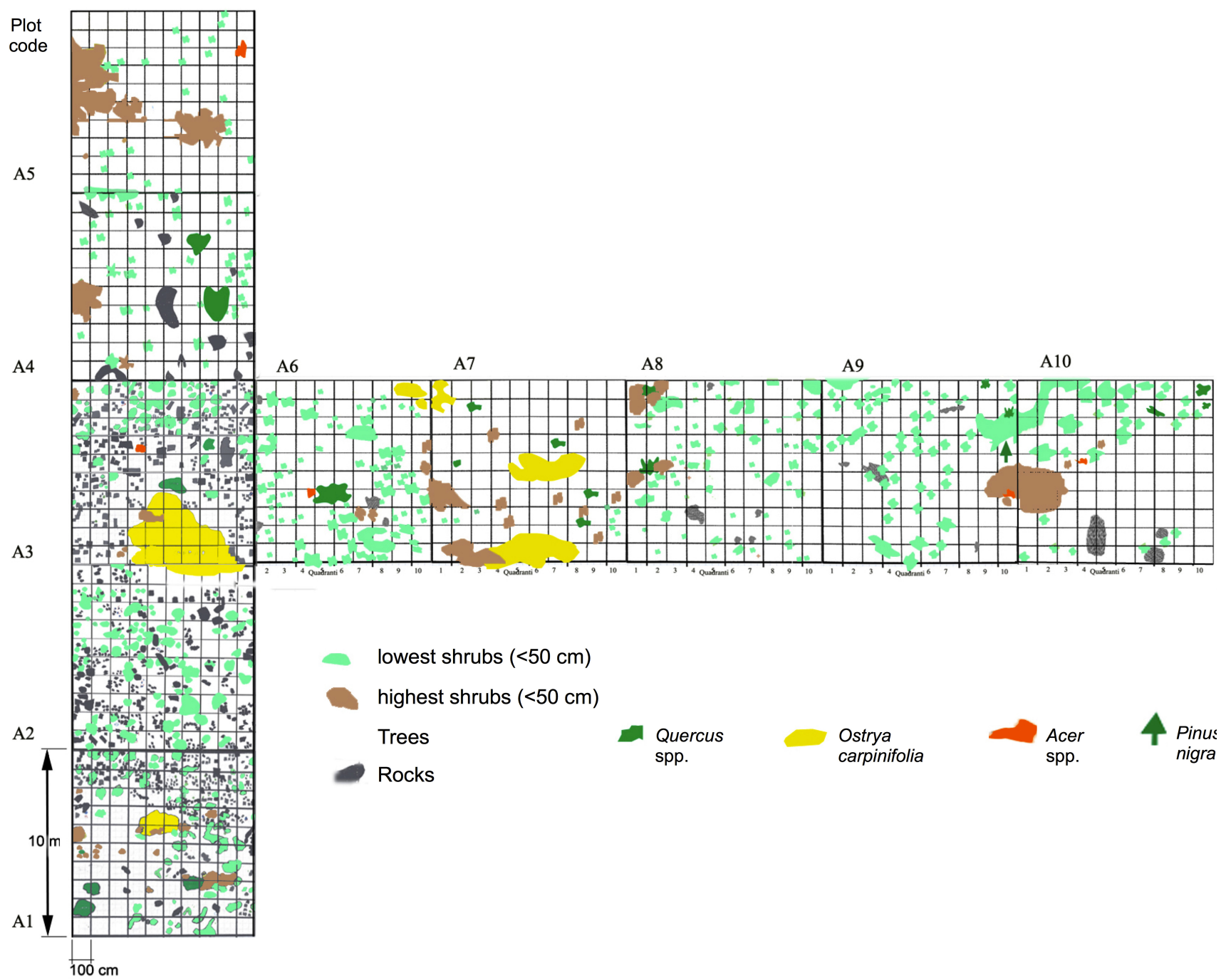

Fig. 3. Vegetation map of the surveyed plots drawn in the 2010 at the beginning of monitoring period. 
Across the 10 plots, we found a mean of $14.8 \pm 11.3 \mathrm{SD}(\min 0 ; \max 45)$ plants per plot with a mean plant density of 0.15 plants $/ \mathrm{m}^{2}$. The mean plant height was $15.3 \mathrm{~cm} \pm 2.5 \mathrm{SD}$ ( $\min 10.1$; $\max 23.0$ ). The mean number of flowers per plot was $36 \pm 23.9 \mathrm{SD}(\min 0, \max 102)$. The mean number of fruiting plants per plot was $2.7 \pm 3.3$ SD (min 0 ; max 15$)$, whereas the mean number of fruits was $4.9 \pm 8.3 \mathrm{SD}(\min 0$; $\max 50)$, thus each plant produced only two capsules on average.

As expected, the number of plants per plot was significantly and positively correlated with the number of flowers $(r=0.94, p<0.001)$, the number of fruiting plants $(\mathrm{r}=0.48, \mathrm{p}<0.001)$ and the number of fruits produced $(\mathrm{r}=0.43, \mathrm{p}<0.001)$. No significant differences between plots $(p>0.05)$ were found as for plant heights and reproductive fitness (the ratio between the number of fruits produced and the number of plant per plot).

Along the two transects, the gradients of slope, aspect and altitude were relatively low. Hence no significant effects were found as regards to the population variables $(p>0.05)$ (e.g. number of individuals or number of fruits produced per plot). Vegetation and rock cover were found slightly variable across the plots (Fig. 3, Table 1). But no significant relationships $(\mathrm{p}>0.05)$ were detected between population variables and rock cover, total vegetation cover or dominant species cover. Due to the fact that the vegetation cover did not show significant changes during the monitored period, it was not further analysed with respect to the temporal trend (see below).

As for population size, a clear negative trend was observed from 2010 to 2015 . The total number of individuals decreased from 237 in 2010 to 61 in
2015 (Fig. 4A, Table 2). A similar trend was observed considering the mean number of plants per plot, which decreased from $23.7 \pm 13 \mathrm{SD}$ (min 5; $\max 40)$ to $6.1 \pm 3.6 \mathrm{SD}(\min 0$; $\max 11)$ (Fig. 4B).

However, the Mann-Whitney U test (after Bonferroni correction) detected significant differences $(p<0.05)$ only in the pairwise comparisons between the years 2010 vs. 2015 and 2012 vs. 2015. Across the analysed temporal interval, the mean population density decreased from 0.24 plants $/ \mathrm{m}^{2}$ to 0.06 plants $/ \mathrm{m}^{2}$.

As for the temporal trend of the number of flowers, number of fruiting plants and number of fruits, they showed a similar decreasing pattern (Electronic Supplement 1), with the highest values in the first of the observed year and the lowest in the last one due to the high collinearity of these variables with the number of individuals per plot. Interesting enough, in 2011 we recorded the lowest number of flowers per plot and the lowest number of fruiting plants. Indeed, neither fruiting plants nor fruits have been detected in this year in the overall monitored area (Electronic Supplement 1). As for plant heights, no differences in pairwise comparisons $(p>0.05)$ were detected from year to year during the monitoring period.

Although the overall dynamic trend of the population can be considered as quite clear, some differences can be highlighted considering the plots separately. During the interval 2010 to 2011, three out of ten plots showed an increasing number of individuals and in the following interval (20112012) four plots showed a similar increase. On the contrary, after 2012 all plots strongly decreased, with a slight increase of a few individuals in three plots only in the last year of monitoring.

Table 1. Percentage cover of vegetation and rock for each of the surveyed plots

\begin{tabular}{|c|c|c|c|c|c|c|c|c|c|c|}
\hline \multirow{2}{*}{ Species } & \multicolumn{10}{|c|}{ Plot code $^{1}$} \\
\hline & A1 & $\mathrm{A} 2$ & A3 & A4 & A5 & A6 & A7 & A8 & A9 & A10 \\
\hline Acer spp. & 0 & 0 & 0 & 0 & 0,5 & 0 & 0 & 0 & 0 & 0 \\
\hline Ostrya carpinifolia & 1.6 & 2.9 & 5.4 & 0 & 0 & 1.8 & 10.8 & 0 & 0.2 & 0.4 \\
\hline Pyrus pyraster & 0 & 0 & 0 & 0.8 & 6.7 & 0 & 0 & 0 & 0 & 0 \\
\hline Pinus nigra & 0 & 0 & 0 & 0 & 0 & 0 & 0 & 0 & 0.3 & 0.15 \\
\hline Fraxinus ornus & 0 & 0 & 0 & 0 & 0 & 0 & 0 & 0 & 0.25 & 0 \\
\hline Quercus spp. & 2.85 & 0 & 1.7 & 3.1 & 0 & 1.7 & 0 & 1.4 & 0.55 & 0.2 \\
\hline Cistus creticus & 13.55 & 8.75 & 12.45 & 7.95 & 5.05 & 18 & 2.6 & 14.45 & 16 & 11.9 \\
\hline Rubus spp. & 1.8 & 0.55 & 0.35 & 0.2 & 0.4 & 0.25 & 0 & 0 & 0.3 & 0 \\
\hline Cytisus scoparius & 5.85 & 0 & 0 & 0 & 0 & 0.4 & 4.35 & 1.8 & 0 & 0 \\
\hline Juniperus communis & 0 & 0 & 0 & 0 & 0 & 0 & 0 & 0 & 1.4 & 2.5 \\
\hline Spartium junceum & 3.85 & 0.35 & 0 & 0 & 0 & 0 & 0 & 0 & 0 & 0 \\
\hline Lonicera etrusca & 0.9 & 0.65 & 0.75 & 2.2 & 4.55 & 0 & 0 & 0 & 0 & 0 \\
\hline Herbs & 68.95 & 77.95 & 73.9 & 78.7 & 83 & 75.45 & 81.95 & 80.75 & 80 & 82.25 \\
\hline Rocks & 0.65 & 9.15 & 5.55 & 7.15 & 0 & 2.4 & 0 & 1.6 & 1 & 2.7 \\
\hline
\end{tabular}

Note: ${ }^{1}$ Plot codes correspond to ones in Fig. 3. 

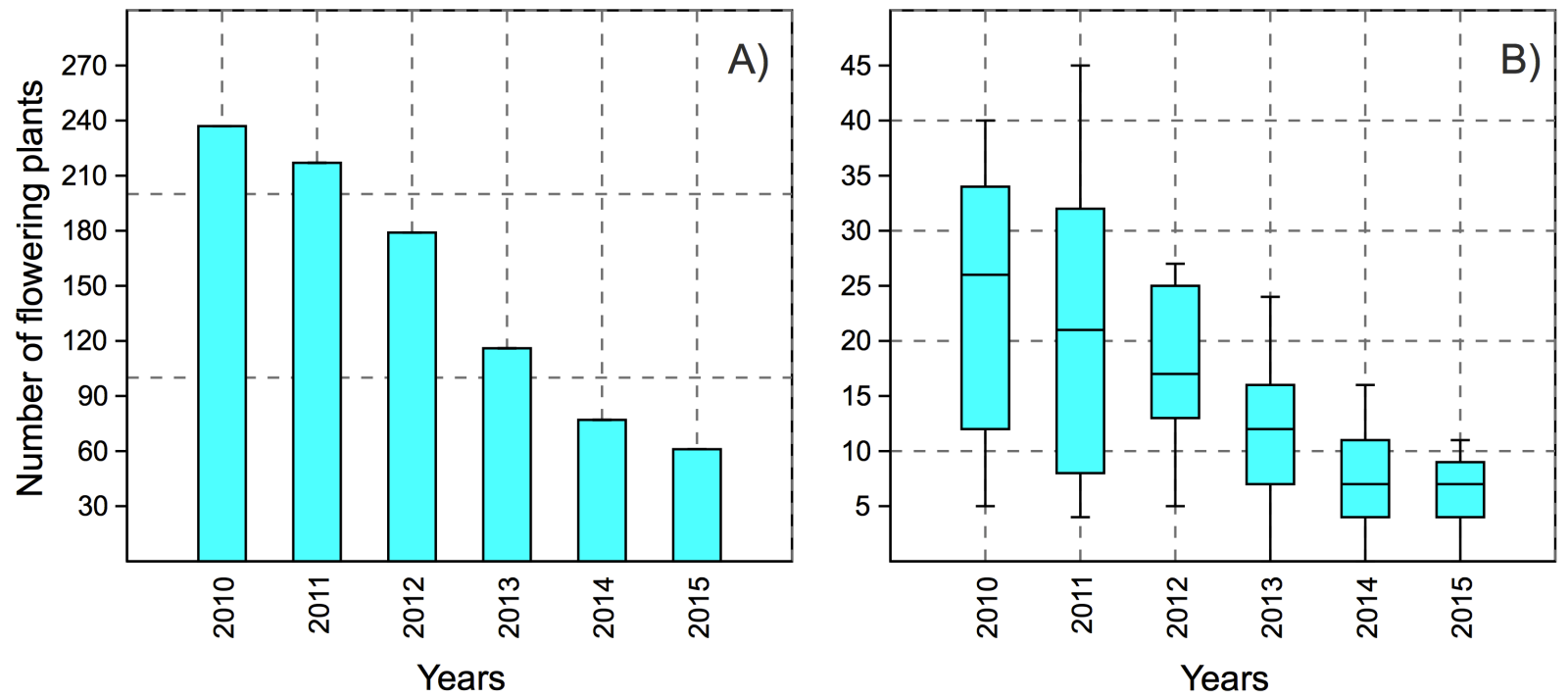

Fig. 4. Number of flowering plants in the Ophrys argolica subsp. biscutella population in the Appennino Lucano-Val d'AgriLagonegrese National Park in 2010-2015. Designations: A: number of flowering plants per year, from 2010 to 2015 , summing all the surveyed permanent plots. B: number of flowering plants recorded per plot in each year. According to the Mann-Whitney test, only the differences 2010 vs. 2015 and 2012 vs. 2015 were significant after Bonferroni correction.

Table 2. Summary statistics of the number of plants per plot during the years of monitoring

\begin{tabular}{lcccccc}
\hline \multirow{2}{*}{ Parameters } & \multicolumn{7}{c}{ Years } \\
\cline { 2 - 7 } & 2010 & 2011 & 2012 & 2013 & 2014 & 2015 \\
\hline Min & 5 & 4 & 5 & 0 & 0 & 0 \\
Max & 40 & 45 & 27 & 24 & 16 & 11 \\
Sum & 237 & 217 & 179 & 116 & 77 & 61 \\
Mean & 23.7 & 21.7 & 17.9 & 11.6 & 7.7 & 6.1 \\
Standard error & 4 & 5 & 2 & 2 & 2 & 1 \\
Variance & 170 & 219 & 49 & 50 & 29 & 13 \\
Standard deviation & 13 & 15 & 7 & 7 & 5 & 4 \\
Median & 24 & 18.5 & 16.5 & 11 & 7 & 7 \\
\hline
\end{tabular}

Analysing the temporal trend of «lost individuals», we detected a huge peak in the 2011 during the anthesis and fruits ripening (average number of lost plants per plot was 16.6 (min 4; $\max 42$ ), all the Mann-Withney pairwise comparisons were significant at $\mathrm{p}<0.05$ ), with a mortality rate of $75 \%$. In the subsequent years the values came back at a markedly lower level, varying on an average from 1.7 individuals per plot to 4.8 individuals per plot (Electronic Supplement 2). Finally the mortality rate of floral spikes decreased from $38 \%$ in 2012 to $3 \%$ in 2015 (Electronic Supplement 2).

The analysis of meteorological data recorded during the sampling interval of 2011 has shown a sharp drop in the minimum temperatures after $4^{\text {th }}$ May, with a decrease of ca. $10^{\circ} \mathrm{C}$ and a late frost event occurred for two consecutive days, between 6 May and 7 May, when the minimum temperatures reached $-2.8^{\circ} \mathrm{C}$ (Electronic Supplement 3). Another frost event, but not so harsh, happened on $4^{\text {th }}$ May 2014 (minimum temperature: $-1.7^{\circ} \mathrm{C}$ ).

\section{Discussion}

In this study, demographic behaviour of the southern Italian endemic Ophrys argolica subsp. biscutella is documented for the first time. In Europe, such studies have mostly involved northern temperate orchids (e.g. Kull, 2002; Whigham \& Willems, 2003). Thus specific studies regarding the genus Ophrys are still scarce (e.g. Vogt-Schilb et al., 2013) and a long-term monitoring spanning over decades has been performed only for a few species (Wells \& Cox, 1991; Hutchings, 1987a,b). Consequently, little specific information is available about the correlation between fluctuations of Ophrys populations and anthropogenic disturbances or climatic drivers (e.g. Hutchings, 2010; VogtSchilb et al., 2015). Nevertheless, such knowledge together with the results from studies regarding other orchid taxa (e.g. Pellegrino \& Bellusci, 2014; Wotavová et al., 2004) can provide a base for assessing the risk of extinction and addressing species conservation actions, also in face of climate change (Swarts \& Dixon, 2009). In fact, it has been documented that orchids show a clear and fast response to environmental changes, including both decline in occurrence and population size (e.g. Whigham \& Willems, 2003).

Although our study was conducted for a limited time interval (six years), its length was in accordance to the suggested monitoring period for biodiversity orchids data (Vogt-Schilb et al., 2013). Due to the lack of previous data about population consistency in the study area, it is not possible to assess whether this negative trend was already undergoing when the monitoring started. 
Some of the monitored plots have shown an opposite trend in the first two years of the study. However, the decrease in the total number of plants in the interval 2010-2011 might indicate that an overall negative trend was yet undergoing, when, at the beginning of May 2011, a severe mortality event occurred. During these days, we observed a sudden drop in minimum temperatures, which reached values below $0^{\circ} \mathrm{C}$ for a few days, an event not usual during this part of the year. As this species does not seem to be able to effectively propagate vegetatively, the lack of fruiting completely vanished the reproductive capacity of the population. It is noteworthy that the other late frost event recorded during the monitoring period, which happened in 2014, seems to have no consequence on the mortality rate in this year, probably due to its short duration and intensity. A similar effect of frost days was observed by Pfeifer et al. (2006) on Himantoglossum hircinum (L.) Spreng.

In accordance with Hutchings (1987b), regarding $O$. sphegodes Mill., a series of unfavourable years, such as the ones we hereby observed, can trigger a negative trend in population dynamics, threatening the population survival. Personal observations in the study area, taken on other orchid species, which have a similar phenology as O. argolica subsp. biscutella, have shown that late frosts can heavily influence their reproductive success, especially, if they occur during both late flowering and fruiting. Particularly, frost events lead to the withering and subsequently to the rotting of the flower spikes (i.e. the plants which we counted as «lost» during the monitoring), or interrupt the maturation of the capsules. In fact, the latter were completely lacking in 2011 . On the other hand, the basal leaves seem to be much more resistant to low temperatures, because they emerge and develop during the autumn - winter period, then progressively dry up during the flowering phase.

Regarding the vegetation cover, surprisingly no significant effects on population size and fitness were detected at the plot level. A possible explanation can be found in the fact that the gradient of variations of these parameters in the study area was not sufficiently high to detect any significant correlations. But it is also possible to hypothesise that an effect can be found investigating at a more detailed spatial scale rather than the one used here $(10 \times 10 \mathrm{~m})$. In this context, the countertrend observed in some of our plots may be due to internal demographic characteristics of the population, such as the age of individuals or to a dormancy effect, rather than to environmental factors. In fact, for $O$. sphegodes it has been demonstrated that individuals may enter for some years (up to eight) in a dormant state (Waite, 1989; Hutchings, 2010) and appear later. Unfortunately, in our case it was not possible to collect reliable data about the dormant state. However, in O. sphegodes for ca. 80\% of the individuals, dormancy were found $\leq 2$ years (Hutchings, 2010), thus, dormancy probably did not significantly affect the general temporal trend observed. In fact, our observations, for six years, largely exceed the prevalent interval of dormancy documented by Hutchings (2010). Nevertheless the presence of dormant individuals in the studied population, during the unfavourable year of 2011, may explain the countertrend observed in some plots (e.g. plot 2), where a marked increase in the number of flowering plants has been observed in 2012. Although specific data regarding $O$. argolica subsp. biscutella are still lacking, a study about Ophrys sphegodes (Hutchings, 1987b) showed that this species, rather closely related to $O$. argolica subsp. biscutella (Hennecke, 2013), has a relatively short life cycle: half-life is in fact of about two years after emergence, a few plants surviving for more than three years after the first emergence and flowering occurs already in the first year above the ground. Thus, due to its short life cycle, it has been argued that one or more unfavourable years, preventing the recruitment of new individuals, determine the rapid ageing of the population which continues to decline even in the years following the unfavourable event, due to the exhaustion of the life cycle of the majority of individuals. On the other hand, a series of favourable years could allow a high rate of seed production, determining a rapid increase of the population size in the following years. However, it cannot be underestimated that the parallel negative trend in the rate of fruiting that we observed can represent a critical element for the ability of a population to maintain itself when it is composed by a small number of individuals, perhaps due to the low pollination success achieved under these conditions.

Although grazing management can heavily influence demographic parameters of Ophrys populations (Hutchings, 2010), in our case there was no evidence that the population decrease can be linked to some kind of land cover or land use change. In fact, during the observation period, no appreciable differences were observed in vegetation cover, type of grazing or grazing load that remained roughly unchanged, although specific 
quantitative data were not collected. In addition, if we consider that several species of Ophrys show a considerable invasive power, e.g. rapidly occupy anthropogenically disturbed sites (Bateman et al., 2018), it could be hypothesised that the large population size observed in the first years of monitoring can be the result of a previously colonisation phase induced by some kind of anthropogenic disturbance. However, our field observations in the years preceding the monitoring period, clearly indicate that no significant events such as fires, soil ploughing or clear cutting occurred in this area. Thus, the habitat included in the permanent plots, albeit semi-natural, has to be considered as relatively stable, because it is linked to the traditional use of mountain pastures that remained substantially unchanged since long time.

\section{Conclusions}

We point out that the only plausible cause responsible for the observed strong population decline of Ophrys argolica subsp. biscutella in the Appennino Lucano-Val d'Agri-Lagonegrese National Park seems to be attributable to the late frost that occurred during the spring of 2011. To clarify whether the observed trends represent a natural demographic fluctuation of this species, spanning over several decades, further studies including a longer observation periods are necessary. Moreover, it would be desirable to specifically investigate whether the current climate change can increase the frequency of late frost events, thus becoming a possible serious threat to the survival of these populations. Thus, in order to be able to assess the relative importance of climate change for population survival, it would be important for Protected Areas to invest more resources in detailed and longer-term monitoring programmes, especially concerning narrow range species with small and fragmented populations, to efficiently address and prioritise the necessary conservation actions.

\section{Supporting Information}

The reproductive parameters of the studied Ophrys argolica subsp. biscutella population (Electronic Supplement 1: Between-years comparison of reproductive features of the Ophrys argolica subsp. biscutella population), rates of the lost spikes and plants in the population (Electronic Supplement 2: Between-years comparison of mortality rate in the studied Ophrys argolica subsp. biscutella population), as well as data on the daily temperature in the study area during 21 April - 12
May 2011 (Electronic Supplement 3: Daily temperatures of spring 2011 during 21 April - 12 May 2011 in the monitored area) may be found in the Supporting Information here.

\section{References}

Bateman R.M., Sramkó G., Paun O. 2018. Integrating restriction site-associated DNA sequencing (RAD-seq) with morphological cladistic analysis clarifies evolutionary relationships among major species groups of bee orchids. Annals of Botany 121(1): 85-105. DOI: 10.1093/ aob/mcx 129

Bartolucci F., Peruzzi L., Galasso G., Albano A., Alessandrini A., Ardenghi N.M.G., Astuti G., Bacchetta G., Ballelli S., Banfi E., Barberis G., Bernardo L., Bouvet D., Bovio M., Cecchi L., Di Pietro R., Domina G., Fascetti S., Fenu G., Festi F., Foggi B., Gallo L., Gottschlich G., Gubellini L., Iamonico D., Iberite M., JiménezMejías P., Lattanzi E., Marchetti D., Martinetto E. et al. 2018. An updated checklist of the vascular flora native to Italy. Plant Biosystems 152(2): 179-303. DOI: 10.1080/11263504.2017.1419996

Bullock J. 1996. Plants. In: W.J. Sutherland (Eds.): Ecological census techniques: a handbook. Cambridge: Cambridge University Press. P. 111-138.

Cortis P., Vereecken N.J., Schiestl F.P., Lumaga M.R.B., Scrugli A., Cozzolino S. 2009. Pollinator convergence and the nature of species' boundaries in sympatric Sardinian Ophrys (Orchidaceae). Annals of Botany 104(3): 497-506. DOI: 10.1093/aob/mcn219

Delforge P. 2016. Orchidés d'Europe, d'Afrique du Nord et do Proche-Orient. $4^{\text {th }}$ ed. Paris: Delachaux et Niestle. 544 p.

Devey D.S., Bateman R.M., Fay M.F., Hawkins J.A. 2008. Friends or relatives? Phylogenetics and species delimitation in the controversial European orchid genus Ophrys. Annals of Botany 101(3): 385-402. DOI: 10.1093/aob/mcm299

EuropeanUnion. 1992. CouncilDirective 92/43/EEC of 21 may 1992 on the conservation of natural habitats and of wild fauna and flora. Available from https://eur-lex.europa. eu/legal-content/EN/TXT/?uri=celex\%3A31992L0043

Fascetti S., Pirone G., Ciaschetti G., Franceschi M., Mazzilli V., Navazio G., Pompili M., Romano V.A. 2006. Il "Faggeto" di Moliterno, Oasi Naturalistica dell'Appennino Lucano. Moliterno: Valentina Porfidio Editore. 111 p.

Fascetti S., Pirone G., Rosati L. 2013. The vegetation of the Maddalena Mountains (Southern Italy). Plant Sociology 50(2): 5-37. DOI: 10.7338/pls2013502/01

Gervasi D.D.L., Selosse M.A., Sauve M., Francke W., Vereecken N.J., Cozzolino S., Schiestl F.P. 2017. Floral scent and species divergence in a pair of sexually deceptive orchids. Ecology and Evolution 7(15): 6023-6034. DOI: $10.1002 /$ ece 3.3147

Hammer Ø., Harper D.A.T., Ryan P.D. 2001. PAST: Paleontological statistics software package for education and data analysis. Palaeontologia Electronica 4(1): 9. 
Hennecke M. 2013. Morphologisches Dendrogramm der Ophrys-Sektionen. Berichte aus den Arbeitskreisen Heimische Orchideen 30(2): 90-108.

Hutchings M.J. 1987a. The Population Biology of the Early Spider Orchid, Ophrys Sphegodes Mill. I. A Demographic Study from 1975 to 1984. Journal of Ecology 75(3): 711-727. DOI: 10.2307/2260201

Hutchings M.J. 1987b. The Population Biology of the Early Spider Orchid, Ophrys Sphegodes Mill. II. Temporal Patterns in Behaviour. Journal of Ecology 75(3): 729 742. DOI: $10.2307 / 2260202$

Hutchings M.J. 2010. The population biology of the early spider orchid Ophrys sphegodes Mill. III. Demography over three decades. Journal of Ecology 98(4): 867-878. DOI: 10.1111/j.1365-2745.2010.01661.x

Johnson S.D., Schiestl F.P. 2016. Floral mimicry. Oxford: Oxford University Press. $176 \mathrm{p}$.

Kull T. 2002. Population dynamics of north temperate orchids. In: T. Kull, J. Arditti (Eds.): Orchid Biology: Review and Perspectives. Vol. 8. Dordrecht: Kluwer Academic Publishers. P. 139-165.

Médail F., Myers N. 2004. Mediterranean Basin. In: R.A. Mittermeier, P. Robles Gil, M. Hoffmann, J. Pilgrim, T. Brooks, C.G. Mittermeier, J. Lamoreaux, G.A.B. da Fonseca (Eds): Hotspots revisited: Earth's biologically richest and most endangered terrestrial ecoregions. Monterrey: Conservation International, Washington and Agrupacion Sierra Madre. P. 144-147.

Pellegrino G., Bellusci F. 2014. Effects of human disturbance on reproductive success and population viability of Serapias cordigera (Orchidaceae). Botanical Journal of Linnean Society 176(3): 408-420. DOI: 10.1111/boj.12204

Pfeifer M., Wiegand K., Heinrich W., Jetschke G. 2006. Long-term demographic fluctuations in an orchid species driven by weather: implications for conservation planning. Journal of Applied Ecology 43(2): 313-324. DOI: 10.1111/j.1365-2664.2006.01148.x

Pignatti S. 1982. Flora d'Italia. Vol. 3. Bologna: Edagricole. 780 p.

Pridgeon A. 1992. The Illustrated encyclopedia of orchids. Portland: Timber Press. 304 p.

Romolini R., Souche R. 2012. Ophrys d'Italia. Saint-Martinde-Londres: Société Occitane d'Orchidologie. 575 p.

Rosati L., Romano V., Bartolucci F., Bernardo L., Bouvet D., Cancellieri L., Caruso G., Conti F., Faraoni F., Banfi E., Galasso G., Lattanzi E., Lavezzo P., Peccenini S., Perrino E.V., Salerno G., Sciandra A., Soldano A., Stinca A., Totta C., Fascetti S. 2017. Contribution to the floristic knowledge of the Maddalena Mountains (Basilicata and Campania, southern Italy). Italian Botanist 3: 73-82. DOI: 10.3897/italianbotanist.3.12519

Rosati L., Coppi A., Farris E., Fascetti S., Becca G., Peregrym M., Tan K., Selvi F. 2019a. The genus Gymnospermium (Berberidaceae) in Italy: Identity and relationships of the populations at the western limit of the genus range. Plant Biosystems 153(6): 796-808. DOI: 10.1080/11263504.2018.1549613

Rosati L., Romano V.A., Cerone L., Fascetti S., Potenza G., Bazzato E., Cillo D., Mecca M., Racioppi R., D’Auria
M., Farris E. 2019b. Pollination features and floral volatiles of Gymnospermium scipetarum (Berberidaceae). Journal of Plant Research 132(1): 49-56. DOI: 10.1007/s10265-018-1073-2

Rosati L., Fascetti S., Romano V.A., Potenza G., Lapenna M.R., Capano A., Nicoletti P., Farris E., de Lange P.J., Del Vico E., Facioni L., Fanfarillo E., Lattanzi E., Cano-Ortiz A., Marignani M., Fogu M.C., Bazzato E., Lallai E., Laface V.L.A., Musarella C.M., Spampinato G., Mei G., Misano G., Salerno G., Esposito A., Stinca A. 2020. New Chorological Data for the Italian Vascular Flora. Diversity 12(1): 22. DOI: 10.3390/d12010022

Sala O.E., Chapin F.S., Armesto J.J., Berlow E., Bloomfield J., Dirzo R., Huber-Sanwald E., Huenneke L.F., Jackson R.B., Kinzig A., Leemans R., Lodge D.M., Mooney H.A., Oesterheld M., Poff N.L., Sykes M.T., Walker B.H., Walker M., Wall D.H. 2000. Global Biodiversity Scenarios for the Year 2100. Science 287(5459): 1770 1774. DOI: $10.1126 /$ science. 287.5459 .1770

Swarts N.D., Dixon K.W. 2009. Terrestrial orchid conservation in the age of extinction. Annals of Botany 104(3): 543-556. DOI: 10.1093/aob/mcp025

Vogt-Schilb H., Geniez P., Pradel R., Richard F., Schatz B. 2013. Inter-annual variability in flowering of orchids: lessons learned from 8 years of monitoring in a Mediterranean region of France. European Journal of Environmental Sciences 3(2): 129-137. DOI: 10.14712/23361964.2015.16

Vogt-Schilb H., Munoz F., Richard F., Schatz B. 2015. Recent declines and range changes of orchids in Western Europe (France, Belgium and Luxembourg). Biological Conservation 190: 133-141. DOI: 10.1016/j.biocon.2015.05.002

Waite S. 1989. Predicting popolution trends in Ophrys sphegodes Mill. In: W. Pritchard (Ed.): Modern Methods in Orchid Conservation. Cambridge: Cambridge University Press. P. 117-127.

Waite S., Hutchings M.J. 1991. The effects of different management regimes on the population dynamics of Ophrys sphegodes: analysis and description using matrix models. In: T.C.E. Wells, J.H. Willems (Eds.): Population Ecology of Terrestrial Orchids. The Hague: SPB Publishing. P. 161-175.

Wells T.C.E., Cox R. 1991. Demographic and biological studies on Ophrys apifera: some results from a 10 years study. In: T.C.E. Wells, J.H. Willems (Eds.): Population Ecology of Terrestrial Orchids. The Hague: SPB Publishing. P. 47-62.

Whigham D.F., Willems J.H. 2003. Demographic studies and life-history strategies of temperate terrestrial orchids as a basis for conservation. In: K.W. Dixon, S.P. Kell, R.L. Barrett, P.J. Cribb (Eds.): Orchid Conservation. Sabah, Borneo: Natural History Publications, Kota Kinabalu. P. $137-158$.

Wotavová K., Balounová Z., Kindlmann P. 2004. Factors affecting persistence of terrestrial orchids in wet meadows and implications for their conservation in a changing agricultural landscape. Biological Conservation 118(3): 271-279. DOI: 10.1016/j.biocon.2003.09.005 


\title{
ТЕНДЕНЦИИ ИЗМЕНЕНИЯ РАЗМЕРА ПОПУЛЯЦИИ OPHRYS ARGOLICA SUBSP. ВISCUTELLA В НАЦИОНАЛЬНОМ ПАРКЕ АППЕННИНО ЛУКАНО-ВАЛЬ-Д'АГРИ-ЛАГОНЕГРЕЗЕ (ИТАЛИЯ)
}

\author{
В. А. Романо, Л. Розати", С. Фашетти \\ Университет Базиликата, Италия \\ *e-mail: leonardo.rosati@unibas.it
}

Целью настоящего исследования стал мониторинг популяции Ophrys argolica subsp. biscutella, opхидеи, эндемичной для юга Итальянского полуострова, относящейся к секции Araniferae. Исследование коснулось основной известной популяции этой орхидеи, расположенной в национальном парке Аппеннино Лукано-Валь-д’Агри-Лагонегрезе (регион Базиликата, Южная Италия). Десять постоянных пробных площадей $(10 \times 10$ м) ежегодно изучались с 2010 по 2015 гг. путем учета всех цветущих растений. Учитывались следующие параметры: высота соцветия, «утерянные» растения, цветущие растения и плодообразование. Проективное покрытие деревьев, кустарников, травянистых растений и площадь открытой скальной поверхности оценивались визуально на меньших учетных площадях размером $1 \times 1$ м, в результате чего была составлена точная карта растительности каждой учетной площади. В отношении высоты растений и репродуктивных показателей популяции не было обнаружено значимых различий между учетными площадями. Аналогично мы не обнаружили статистически значимой корреляции популяционных параметров с особенностями растительности или параметрами окружающей среды (т.е. склон, аспект). Напротив, была обнаружена сильно выраженная негативная тенденция в отношении общей численности особей в популяции (от 237 особей в 2010 г. до 61 особи в 2015 г.) и числа растений на учетную площадь, снизившейся за период исследования с 23.7 особей на площадь до 6.1 особи на учетную площадь. Параметры репродуктивной биологии (т.е. число цветков, плодообразование) показали аналогичную тенденцию к снижению. Относительно «утерянных» особей, мы отметили более высокую их долю в популяции в 2011 г. (в среднем было зарегистрировано 16.6 утерянных растений на учетную площадь), при этом были отмечены 75\%-ная утрата соцветий и отсутствие завязавшихся плодов. Хотя выпас может сильно повлиять на демографические параметры популяций видов рода Ophrys, не было никаких свидетельств каких-либо изменений в почвенном покрове или землепользовании в рамках настоящего исследования. Не наблюдалось никаких заметных различий в растительном покрове, типе выпаса и нагрузке выпаса. Более того, в этом районе не было отмечено никаких серьезных нарушений среды. Наконец, анализ метеорологических данных, собранных в течение периода исследования, позволяет утверждать, что сильное снижение демографических показателей популяции Ophrys argolica subsp. biscutella в национальном парке Аппеннино Лукано-Вальд’Агри-Лагонегрезе, в основном, связано с поздними заморозками, произошедшими весной 2011 г.

Ключевые слова: Orchidaceae, демография, особо охраняемая природная территория, поздние заморозки, популяционная динамика, редкий вид растений, эндемичный вид 